\title{
An Analysis of Entrepreneurial Perspective of Public Sector; A Systematic Literature Review from 1990 to 2016
}

\author{
Asghar Ali ${ }^{1}$, Sidra Irfan ${ }^{2}$, Yaamina Salman
}

\begin{abstract}
The concept of entrepreneurship in the public sector has prompted a discussion and debate in the public management literature especially with the movement of new public management (NPM) which was initiated to improve the performance of public sector organizaitons. In this article, the phenomenon of public entrepreneurship is reviewed systematically by analyzing 90 research articles published between 1990 and 2016. Articles were analyzed based upon the following themes of public entrepreneurship; definitions of public entrepreneurships, goals of entrepreneurship into public sector, issues and limitation, influencing factors, and main research streams are the main themes analyzed in this systematic literature review. Changing institutional routines, introducing innovation for efficient service delivery, and add social value into public services were the main goals which are to be achieved by the entrepreneurship into public sector. Entrepreneurial practices, paradigm, method, theories, contextual antecedents and implications were the main research streams revealed in this review. Further reviews could be conducted by focusing on exploiting entrepreneurial opportunities in the public sector.
\end{abstract}

Key Words: Entrepreneurship; public entrepreneurship, definitions of entrepreneurship

\section{Introduction}

Entrepreneurship has been focused field of research among researchers and practitioners since 1980s (Doherty, Thompson, \& Spear, 2006). Its significance has been well established due to its pivotal role in venture creation by exploiting opportunities, bringing innovation, creativity and promoting sustainable economic development by creating new jobs in every economy (Wagner \& Schaltegger, 2010). Generally the word "entrepreneurship" is associated with private sector (Salazar, 1997), for creating new firms by those individuals who have unique cognitive characteristics, they are called

1 Lecturer at Department of Management Sciences, Virtual University of Pakistan. asghar.ali@vu.edu.pk 2 Assistant Professor at Institute of Administrative Sciences, University of the Punjab, Lahore, Pakistan. 3 Assistant Professor at Institute of Administrative Sciences, University of the Punjab, Lahore, Pakistan.

\begin{tabular}{ll} 
ARTICLE HISTORY & \\
05 Sep, 2018 Submission Received & 29 Oct, 2018 First Review \\
\hline 12 Mar, 2019 Second Review & 17 Aug, 2019 Third Review \\
\hline 30 Aug, 2019 Accepted &
\end{tabular}


entrepreneurs but this perspective of entrepreneurship has been considered too narrow and various significant attempts has been made by the scholars and practitioners to stretch its scope into public sector for efficient and effective delivery of public services (Zerbinati \& Souitaris, 2005). Eventually, the phenomenon of entrepreneurship entered into the discourse of public management literature across a number of public sector organizations in different countries (Edwards, Jones, Lawton, \& Llewellyn, 2002) but it's role into public sector has remained controversial (Llewellyn \& Jones, 2003) due to the nature and structure of public sector organizations.

Interestingly, the concept of entrepreneurship in the public sector has prompted a discussion and debate in the public management literature especially with the movement of new public management (NPM). NPM was initiated to improve the performance of public sector organizations and to let public managers manage entrepreneurially and to make it possible for public managers to work like private sector entrepreneurs (Bernier \& Hafsi, 2007). In the public sector, to work entrepreneurially by the public managers and politicians is very difficult due to the democratic and bureaucratic values (Llewellyn \& Jones, 2003; Zerbinati \& Souitaris, 2005). Public sector organizations are managed by strong and well rooted democratic norms, culture, and values whereas entrepreneurship promotes risk taking, aggressiveness, autonomy, innovation and disrespect for certain culturally embedded traditions. This difference has hindered the adaptation of entrepreneurial models into public sector organizations (Zerbinati \& Souitaris, 2005).

Public sector organizations have experienced various reforms in all over the world due to the escalated pressures upon governments for improved effectiveness through efficiency and to cater citizens' needs in a responsive manner (Zampetakis \& Moustakis, 2007b). Moreover, it was the hallmark of NPM movement to bring innovation in the public sector and to transform public organizations into more responsive agencies towards the efficient and effective provision of public service delivery (Mack, Green, \& Vedlitz, 2008).

This substantial development envisioned by NPM movement in delivering public services has considered entrepreneurial mindset of public managers and politicians as an important characteristic. Which enables the public managers to be entrepreneurial in their approach by exploiting opportunities irrespective of resources they own, doing innovative and new things and be willing to escape themselves from old routines to pursue opportunities (Zampetakis \& Moustakis, 2010). Traditional approaches to fulfill the complex and emerging demands of $21^{\text {st }}$ century are not sufficient to meet the evolving challenges of governments for public administration which has forced the public managers to portray and devise new public management tools (Moghaddam, Khorakian, \& Maharati, 2015). To bring efficiency and effectiveness into public sec- 
tor has been a key challenge for public policy makers and civil servants. Since 1970, various initiatives and reforms have been taken and implemented around the world in which government structures have been transformed to adapt changes efficiently and effectively (Zampetakis \& Moustakis, 2007a).

Moreover, scholars like Seo and Chung (2012) argues that entrepreneurial orientation of public sector managers for managing public services, agencies, and enterprises is considered as a vital tool for upgrading and developing public organizations' efficiency and effectiveness which satisfy citizens' demands. It is challenging to bring entrepreneurial approach into public sector due to the difference in orientation of public and private sector. Entrepreneurial development has become a significant determinant to ensure economically rational and market based practice for the design and implementation of public policy and services (Vecchi, Brusoni, \& Borgonovi, 2014). Thus, the importance of incorporating entrepreneurial methods into public sector has been widely acclaimed and acknowledged. Political agents are becoming more concerned to foster entrepreneurial methods into public sector agencies to improve their performance (Luke \& Verreynne, 2006; Moon, 1999). Researchers claimed that practices of private sector entrepreneurship could be applied to public sector due to its emergence as leading force in public management literature (Sadler, 2000).

Insofar, entrepreneurial spirit and its application into public sector for improved performance of state enterprises have been discussed with its various implications. However, what is public entrepreneurship or how entrepreneurship is defined with particular reference to public sector?, What are the emerging models/methods of entrepreneurship in public sector?, Are the practices of public entrepreneurship are different from private sector entrepreneurship?, these are the few conceptual and theoretical contemporary issues being discussed into entrepreneurship literature by the scholars?

To get answers to these conceptual and theoretical issues, this study was conducted to investigate the phenomenon of entrepreneurship with reference to public sector by adopting the methodology of systematic literature review. Methodology of this systematic literature review of public entrepreneurship is adopted with the review of (De Vries, Bekkers, \& Tummers, 2016) which was conducted on innovation in public sector. This study endeavored to explore the concept of public entrepreneurship, its current practices, goals, limitations and possibilities, major research streams, their emergence, convergence, and divergence points, antecedents and its outcomes in public sector. To pursue these objectives, following pertinent research questions were posed;

1. What definitions of public sector entrepreneurship are being used? 
2. What are the goals of public sector entrepreneurship?

3. What are the limitations and possibilities of entrepreneurship in the public sector?

4. What are the main streams/types of public sector entrepreneurship?

5. What are the main antecedents which influence the public sector entrepreneurship?

Entrepreneurship is a multidimensional concept and its applicability into public management literature has broad breath and scope. Its practices are considered to be innovative and productive both in public and private sectors (Mack et al., 2008; Seo \& Chung, 2012).

This study has significant contribution to literature as it was conducted by systematic review of literature on public entrepreneurship. Systematic review are different from general literature review as they are guided and govern by rigorous and objective methods and structure of this systematic review is adopted from (De Vries et al., 2016) that systematic literature review is conducted on innovation in public sector.

The next section presents the detailed methodology followed to complete this systematic literature review on public entrepreneurship. Followed by results section which presents comprehensive findings revealed by this study about public entrepreneurship phenomenon.

\section{Study Methodology}

\subsection{Searching of literature on public entrepreneurship}

Literature on public entrepreneurship was explored rigorously by using the following systematic steps and procedures to ensure maximum objectivity. Period from 1990 to May 24, 2016 was selected for literature search published on public entrepreneurship to include various seminal contributions like Bellone and Goerl (1992) paper on reconciling public entrepreneurship and democracy and various other significant studies conducted by (Perlmutter \& Cnaan, 1995; Sadler, 2000; Shane \& Venkataraman, 2000; Terry, 1993; Teske \& Schneider, 1994) and emergence of NPM movement which refers to apply entrepreneurial methods in public administration and management (Mark, 2015).

A search into six electronic databases was carried out namely; ISI web of knowledge; Emerald; J-Store; Taylor \& Francis; Wiley; and Elsevier (Science Direct) in order to include extensive literature on public entrepreneurship. In all the databases, the key term "public entrepreneurship" with inverted commas' was searched with a filter 
Table 1: Literature Search Criteria

\begin{tabular}{|c|c|c|}
\hline Sr. No. & Search Factors & Particulars \\
\hline 1 & Literature Search & Public Entrepreneurship \\
\hline 2 & Search Discipline & Public Administration Domain \\
\hline 3 & Language & English \\
\hline 4 & Publication Period & $1990-2016$ \\
\hline 5 & Electronic Databases & ISI-Web of Knowledge \\
& & Emerald \\
& & Taylor \& Francis \\
& & Wiley \\
& & Elsevier (Science Direct) \\
\hline 6 & Search Key Word & "Public Entrepreneurship" \\
\hline
\end{tabular}

of time duration from 1990 to 2016 and the last search was conducted on May 24, 2016. The search results with the term "public entrepreneurship" revealed 572 articles in total from all six databases. Detailed literature search criteria are mentioned in the following table;

Hence, the above-mentioned criteria were used to search the literature on public entrepreneurship, a potential limitation by the part of researchers is acknowledged as only databases which were accessible to researchers as mentioned and were searched with the key word "public entrepreneurship" there is possibility of missing some significant contributions.

\subsection{Eligibility criteria for studies selection}

After conducting the initial search on the six databases mentioned in table 1; following eligibility criteria was used to include research studies into consideration for systematic review on public entrepreneurship.

\subsection{Selection of studies}

After applying the search criteria on all the six electronic databases, search results 572 results were appeared. Based on the eligibility criteria 90 research articles were selected after removing repetitions and book reviews. Figure 1; depicts the selection process used to select the articles. All the articles were carefully screened by the researchers, their titles and abstracts were studied and selected articles were studied thoroughly and meticulous analysis was carried out, an excel spread sheet was maintained to ensure maximum quality. Data about articles publication year, 
Table 2: Articles Eligibility Criteria

\begin{tabular}{|c|c|c|}
\hline Sr. No. & Eligibility Factors & Particulars \\
\hline 1 & Field of Studies & Studies dealing with entrepreneurship in the public sector. \\
\hline 2 & Topic/Issue of Study & $\begin{array}{l}\text { Studies core issue should be public entrepreneurship, reflected } \\
\text { in their topics, titles, abstracts and objectives were selected for } \\
\text { review. } \\
\text { Studies having following key words (Public Entrepreneurship, } \\
\text { Public Sector Entrepreneurship, Public Entrepreneur, and } \\
\text { Entrepreneurship in the Public Sector) were included. }\end{array}$ \\
\hline 3 & Design of Studies & $\begin{array}{l}\text { Both empirical and conceptual studies were eligible and all } \\
\text { research designs like survey, case study, descriptive, explorato- } \\
\text { ry, causal and mixed methods were included. }\end{array}$ \\
\hline 4 & Publication Status & $\begin{array}{l}\text { Only published research articles were selected for systematic } \\
\text { review on public entrepreneurship. }\end{array}$ \\
\hline
\end{tabular}

title, journal, study objective, research questions/hypothesis, variables, main research findings, contribution were derived from 90 selected articles. Moreover, data about the main research questions, like definition of entrepreneurship in the public sector, goals of entrepreneurship in public sector, research streams, limitations and possibilities, influencing factors and outcomes were derived to get answers to posed by this systematic review.

Articles searching on mentioned online databases, initial screening, download-

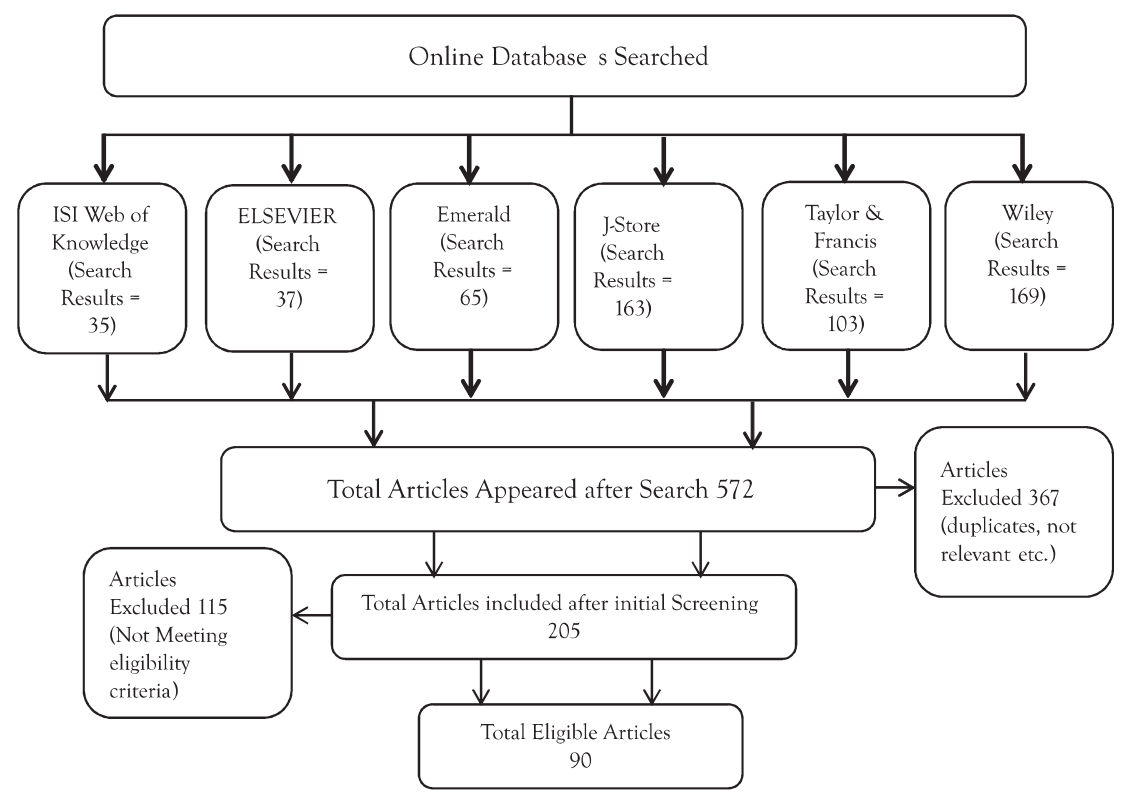

Figure 1: Flow Chart of Articles Searching, Screening and Selection 
ing, and reading was rigorously performed. Although maximum efforts were made to ensure objectivity but limitation of subjectivity (De Vries et al., 2016) could never be ignored because of certain limitations. All the 90 selected articles were thoroughly reviewed and studied by the researchers and comprehensive analysis was performed on excel spreadsheet deriving relevant themes about public entrepreneurship definitions, goals, it's limitations and possibilities into government sector in the presence of strong democratic values and bureaucratic system, it's antecedents and major influencing factors and outcomes.

\section{Results of Systematic Literature Review}

In this section, complete results of this systematic literature review are presented.

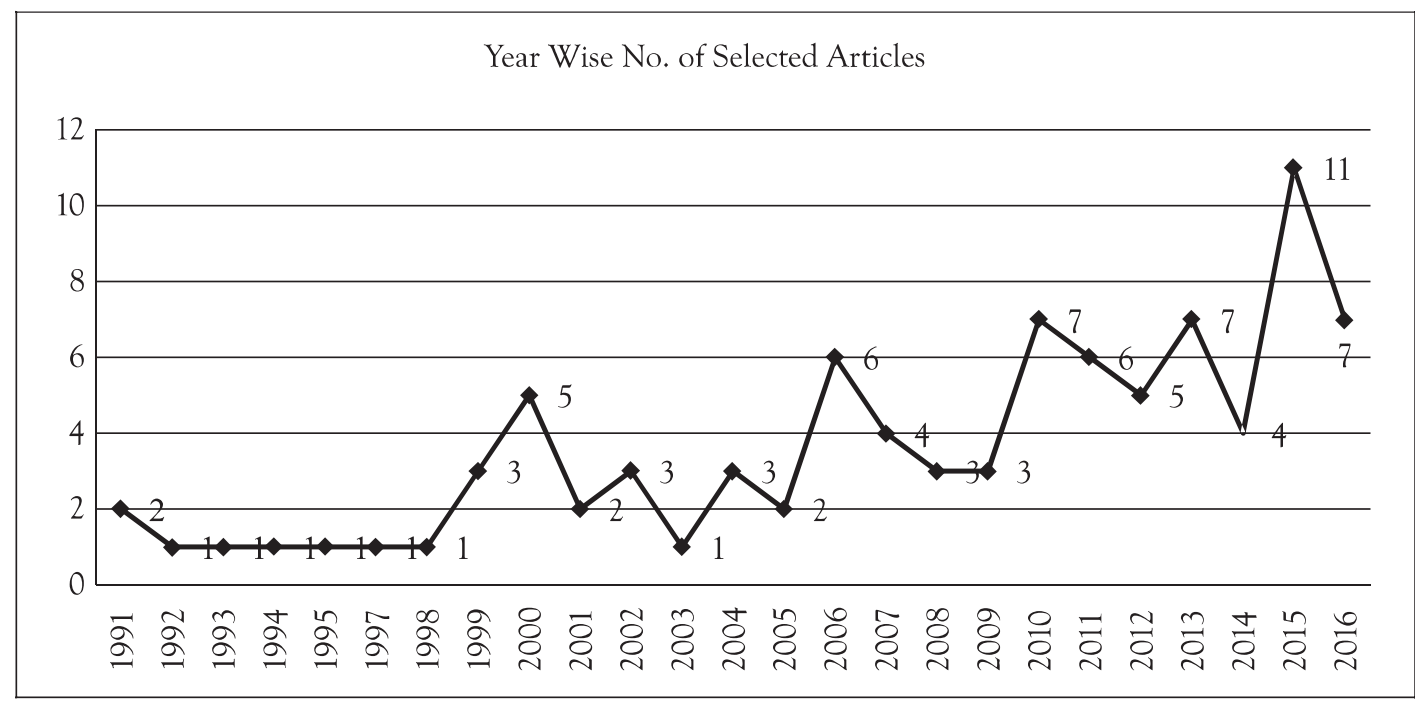

Years 1991 to 2016

Chart 1: Year Wise Articles

Chart 1 depicts year wise number of articles included in systematic literature review of public entrepreneurship. It reveals that majority articles on public entrepreneurship were published between the periods of 2011 to 2016 as $40(44.44 \%)$ articles were published during this period. Moreover, 34(37.78\%) articles were published in 2001 to 2010, and 16(17.78\%) articles were published during 1990 to 2000. Hence, it could be concluded that majority articles 74 (82.22\%) included in this systematic literature review on public entrepreneurship were published during 2001 to 2016.

Continent wise analysis showed majority of the articles 37(41.11\%) were published in North American countries, and 36(40\%) were published in European countries. Hence, it could be concluded that $73(81.11 \%)$ articles were published in European and North American countries. 
Table 3: Continent Wise No. of Articles

\begin{tabular}{|c|c|c|c|}
\hline Sr. & Continents & No. of Articles & Percentage \\
\hline 1 & Asia & 10 & $11.11 \%$ \\
\hline 2 & Australia & 6 & $6.67 \%$ \\
\hline 3 & Europe & 36 & $40 \%$ \\
\hline 4 & North America & 37 & $41.11 \%$ \\
\hline 5 & South America & 1 & $1.11 \%$ \\
\hline & Total & 90 & $100 \%$ \\
\hline
\end{tabular}

Table 4 depicts country wise number of published articles which were finally got eligible for this systematic literature review. Overall, articles from 23 countries are got selected for this review. Analysis reveals that majority of the research studies $33(36.67 \%)$ were conducted in USA, followed by $12(13.33 \%)$ were conducted in UK. Thus, $45(50 \%)$ studies were conducted in USA and UK only. It means researchers from USA and UK are more concerned about the phenomenon of public entrepreneurship as compared to other countries.

Table 4: Country Wise No. of Articles

\begin{tabular}{|c|c|c|c|}
\hline Sr. & Country & Frequency & Percentage \\
\hline 1 & Australia & 4 & 4.44 \\
\hline 2 & Belgium & 2 & 2.22 \\
\hline 3 & Brazil & 1 & 1.11 \\
\hline 4 & Canada & 4 & 4.44 \\
\hline 5 & China & 3 & 3.33 \\
\hline 6 & Denmark & 3 & 3.33 \\
\hline 7 & Finland & 1 & 1.11 \\
\hline 8 & France & 2 & 2.22 \\
\hline 9 & Germany & 2 & 2.22 \\
\hline 10 & Greece & 3 & 3.33 \\
\hline 11 & Iran & 2 & 2.22 \\
\hline 12 & Ireland & 1 & 1.11 \\
\hline 13 & Israel & 1 & 1.11 \\
\hline 14 & Italy & 2 & 2.22 \\
\hline 15 & New Zealand & 2 & 2.22 \\
\hline 16 & Pakistan & 2 & 2.22 \\
\hline
\end{tabular}




\begin{tabular}{|c|c|c|c|}
\hline 17 & South Korea & 1 & 1.11 \\
\hline 18 & Spain & 3 & 3.33 \\
\hline 19 & Sri Lanka & 1 & 1.11 \\
\hline 20 & Sweden & 4 & 4.44 \\
\hline 21 & Switzerland & 1 & 1.11 \\
\hline 22 & UK & 12 & 13.33 \\
\hline 23 & USA & 33 & 36.67 \\
\hline & Total & 90 & 100.00 \\
\hline
\end{tabular}

Furthermore, Australia 4(4.44\%), Sweden 4(4.44\%), Canada4 (4.44\%), China 3 (3.33\%), Denmark 3 (3.33\%), Greece 3 (3.33\%), Spain $3(3.33 \%)$, Iran 2(2.22\%), Pakistan 2(2.22\%), New Zealand 2(2.22\%), Belgium 2(2.22\%), France 2(2.22\%), Germany 2(2.22\%), and Italy 2(2.22\%) studies were conducted. Rest of the countries had only 1 research articles included in this review.

Table 5: Journal Wise No. of Articles

\begin{tabular}{|c|c|c|c|}
\hline Sr. & Journal & No. of Articles & Percentage (\%) \\
\hline 1 & Entrepreneurship \& Regional Development & 11 & 12.22 \\
\hline 2 & Public Administration Review & 11 & 12.22 \\
\hline 3 & Public Management Review & 4 & 4.44 \\
\hline 4 & Procedia Social and Behavioral Sciences & 3 & 3.33 \\
\hline 5 & Public Administration & 3 & 3.33 \\
\hline 6 & Australian Journal of Public Administration & 2 & 2.22 \\
\hline 7 & European Journal of Marketing & 2 & 2.22 \\
\hline 8 & European Management Review & 2 & 2.22 \\
\hline 9 & Journal of Enterprising Communities: People and Places & 2 & 2.22 \\
\hline 10 & in the Global Economy & 2 & 2.22 \\
\hline 11 & Journal of Public Administration Research and Theory & 2 & 2.22 \\
\hline 12 & Local Government Studies & 2 & 2.22 \\
\hline 13 & Academy of Management Review & 1 & 1.11 \\
\hline 14 & Administration in Social Work & 1 & 1.11 \\
\hline 15 & Asia Pacific Journal of Public Administration & 1 & 1.11 \\
\hline 16 & Emerging Markets Finance and Trade & 1 & 1.11 \\
\hline 17 & Entrepreneurship Theory and Practice & 1 & 1.11 \\
\hline
\end{tabular}




\begin{tabular}{|c|c|c|c|}
\hline 18 & European Journal of Innovation Management & 1 & 1.11 \\
\hline 19 & European Planning Studies & 1 & 1.11 \\
\hline 20 & Financial Accountability \& Management & 1 & 1.11 \\
\hline 21 & HEC Montréal & 1 & 1.11 \\
\hline 22 & Industry and Innovation & 1 & 1.11 \\
\hline 23 & Innovation: Management, Policy \& Practice & 1 & 1.11 \\
\hline 24 & $\begin{array}{l}\text { Innovation: The European Journal of Social Science } \\
\text { Research }\end{array}$ & 1 & 1.11 \\
\hline 25 & $\begin{array}{l}\text { International Journal of Entrepreneurial Behavior \& } \\
\text { Research }\end{array}$ & 1 & 1.11 \\
\hline 26 & International Journal of Manpower & 1 & 1.11 \\
\hline 27 & International Journal of Public Administration & 1 & 1.11 \\
\hline 28 & International Journal of Social Economics & 1 & 1.11 \\
\hline 29 & International Public Management Journal & 1 & 1.11 \\
\hline 30 & Journal of Business Venturing & 1 & 1.11 \\
\hline 31 & Journal of Economic Education & 1 & 1.11 \\
\hline 32 & Journal of Economic Policy Reform & 1 & 1.11 \\
\hline 33 & Journal of International Development & 1 & 1.11 \\
\hline 34 & Journal of Nonprofit \& Public Sector Marketing & 1 & 1.11 \\
\hline 35 & Journal of Small Business \& Entrepreneurship & 1 & 1.11 \\
\hline 36 & Journal of Small Business and Enterprise Development & 1 & 1.11 \\
\hline 37 & Journal of the American Planning Association & 1 & 1.11 \\
\hline 38 & Journal of World Business & 1 & 1.11 \\
\hline 39 & Korean Review of Public Administration & 1 & 1.11 \\
\hline 40 & $\begin{array}{l}\text { Labour \& Industry: A Journal of the Social and Econom- } \\
\text { ic Relations of Work }\end{array}$ & 1 & 1.11 \\
\hline 41 & $\begin{array}{l}\text { Marketing Communications for Local Nonprofit Orga- } \\
\text { nizations }\end{array}$ & 1 & 1.11 \\
\hline 42 & $\begin{array}{l}\text { Network of Asia-Pacific Schools and Institutes of Public } \\
\text { Administration and Governance }\end{array}$ & 1 & 1.11 \\
\hline 43 & Political Science and Politics & 1 & 1.11 \\
\hline 44 & Politics \& Policy & 1 & 1.11 \\
\hline 45 & Public Administration and Development & 1 & 1.11 \\
\hline 46 & Qualitative Research in Accounting \& Management & 1 & 1.11 \\
\hline 47 & Regional Studies & 1 & 1.11 \\
\hline 48 & Research Policy & 1 & 1.11 \\
\hline
\end{tabular}




\begin{tabular}{|l|c|c|c|}
\hline 49 & Review of Policy Research & 1 & 1.11 \\
\hline 50 & State \& Local Government Review & 1 & 1.11 \\
\hline 51 & Strategic Entrepreneurship Journal & 1 & 1.11 \\
\hline 52 & The Journal of Economic Education & 1 & 1.11 \\
\hline 53 & The Journal of Technology Transfer & 1 & 1.11 \\
\hline 54 & Tourism \& Management Studies & 1 & 1.11 \\
\hline 55 & Utilities Policy & 1 & 1.11 \\
\hline 56 & World Futures & 1 & 1.11 \\
\hline & Total & 90 & 100 \\
\hline
\end{tabular}

Table 5 depicts total number of journals in which 90 selected articles were published. Articles selected for review on public entrepreneurship were published in 56 different journals. Majority of the articles 11 (12.22\%) were published in Public Administration review followed by same frequency published in Entrepreneurship \& Regional Development journal. In Public Management Review 4(4.44\%), 3 (3.33\%) were in Public Administration, and 3(3.33\%) Procedia Social and Behavioral Sciences journal. On the basis journals analysis, $65(72.22 \%)$ articles were published in public administration and public policy, and public management journals.

Table 6: Nature Wise No. of Articles

\begin{tabular}{|c|c|c|c|}
\hline Sr. & Nature of Papers & No. of Articles & Percentage \\
\hline 1 & Empirical & 54 & 60 \\
\hline 2 & Conceptual & 27 & 30 \\
\hline 3 & Theoretical & 9 & 10 \\
\hline & Total & 90 & 100 \\
\hline
\end{tabular}

Table 6 reveals that 54(60\%) articles included in the review were empirical studies conducted on various perspectives of public entrepreneurship. Moreover, 27(30\%) papers were conceptual in nature, and $9(10 \%)$ articles were theoretically written. Majority articles were $60 \%$ were empirical and $30 \%$ were conceptual.

Table 7: Strategy Wise No. of Articles

\begin{tabular}{|c|c|c|c|}
\hline Sr. & Strategy of Papers & No. of Articles & Percentage \\
\hline 1 & Qualitative & 28 & 51.85 \\
\hline 2 & Quantitative & 23 & 42.59 \\
\hline 3 & Mixed Methods & 3 & 5.56 \\
\hline & Total & 54 & 100 \\
\hline
\end{tabular}


Table 7 presents strategy wise number of articles. It reveals that out of 54 empirical papers $28(51.85 \%)$ were qualitative research papers, $23(42.59 \%)$ used quantitative research strategy, and 3(5.56\%) used mixed method research strategy. Hence, it could be concluded that majority articles used qualitative and quantitative research strategy. Further, categories of various research designs used in qualitative and quantitative research strategy are presented in next tables.

Table 7.1: Qualitative Paper Categories

\begin{tabular}{|c|c|c|c|}
\hline Sr. & Qualitative Paper Categories & No. of Articles & Percentage \\
\hline 1 & $\begin{array}{c}\text { Case Studies - Grounded Theory } \\
\text { Method }\end{array}$ & 1 & 3.57 \\
\hline 2 & Discourse Analysis & 1 & 3.57 \\
\hline 3 & Exploratory - Case Study & 1 & 3.57 \\
\hline 4 & $\begin{array}{c}\text { Exploratory - Interviews - Discursive } \\
\text { pragmatism }\end{array}$ & 1 & 3.57 \\
\hline 5 & Qualitative - Case Study & 14 & 50 \\
\hline 6 & Qualitative - Ethnography & 1 & 3.57 \\
\hline 7 & Qualitative - Exploratory & 3 & 3.57 \\
\hline 8 & $\begin{array}{c}\text { Qualitative - IDIs, Participant Observa- } \\
\text { tions, and Archival Material }\end{array}$ & 1 & 7.14 \\
\hline 9 & $\begin{array}{c}\text { Qualitative - Interviews and secondary } \\
\text { data analysis }\end{array}$ & 2 & 3.57 \\
\hline 10 & Qualitative - Mix and Match Approach & 1 & 7.14 \\
\hline 11 & Qualitative - Triangulation & 2 & 100 \\
\hline & Total & 28 & \\
\hline
\end{tabular}

Table 7.1 depicts the various designs used in qualitative research papers included in this review. It reveals that $14(50 \%)$ articles used case study design. Followed by $3(10.71 \%)$ exploratory design, $2(7.14 \%)$ used interviews and secondary data analysis and 2(7.14) used triangulation approach as research design. It could be concluded that majority used case study design while analyzing phenomenon of public entrepreneurship.

Table 7.2 presents different types of quantitative research design used in the articles. It reveals that out of total 23 articles which used quantitative design, 15(65.22\%) used survey approach, 2(8.70\%) used secondary data analysis, and 2(8.70\%) used secondary data published by GEMs (Global Entrepreneurship Monitor). Majority $65.22 \%$ articles used survey design. 
Table 7.2: Quantitative Paper Categories

\begin{tabular}{|c|c|c|c|}
\hline Sr. & Quantitative Paper Categories & No. of Articles & Percentage \\
\hline 1 & Bibliometric Analysis & 1 & 4.35 \\
\hline 2 & Longitudinal & 1 & 4.35 \\
\hline 3 & Quantitative - Survey & 15 & 65.22 \\
\hline 4 & Quantitative - Secondary Data Analysis & 2 & 8.70 \\
\hline 5 & Quantitative - Descriptive & 1 & 4.35 \\
\hline 6 & Research - Action Approach & 1 & 4.35 \\
\hline 7 & Secondary Data Analysis - GEMs & 2 & 8.70 \\
\hline & Total & 23 & 100 \\
\hline
\end{tabular}

\subsection{Definitions of entrepreneurship in public sector}

This section presents the various definitions of entrepreneurship and entrepreneur as an individual used in the selected research studies. The most interesting finding is that only $21(23.33 \%)$ out of 90 selected articles used the definition of entrepreneurship and an entrepreneur in their research articles. In the literature, there is very little agreement on exactly how to define entrepreneurship (Harper-Anderson $\&$ Gooden, 2016) and the concept of public entrepreneurship recently appeared into the mainstream literature of entrepreneurship (Zerbinati \& Souitaris, 2005).

Mostly, definitions focused personal characteristics of entrepreneurs and their approaches towards innovation, creativity, and opportunity exploitation (Harper-Anderson \& Gooden, 2016). While exploring the definition of public entrepreneurship it is seen as having the market based features of entrepreneurship with an addition of creating social capital for social benefits (Edwards et al., 2002). While analyzing various aspects of definition used in the articles it was revealed that entrepreneurship was defined in multiple perspectives. Following table depicts the various perspectives of definition along with their frequency and percentage.

Table 8: Definition Perspectives

\begin{tabular}{|c|c|}
\hline Definition Perspective & $\mathbf{N}$ \\
\hline Entrepreneur as an individual & $7(33.33 \%)$ \\
\hline Entrepreneurship as a process & $5(23.81 \%)$ \\
\hline Entrepreneurship as a task & $5(23.81)$ \\
\hline Entrepreneurship as a method & $3(14.29)$ \\
\hline Entrepreneurship as a Field & $1(4.76 \%)$ \\
\hline Total & $21(100 \%)$ \\
\hline
\end{tabular}


Moreover, analysis of these perspectives revealed numerous key factors discussed in definitions of entrepreneurship in public sector which are presented in the following table along with description and references.

Table 8.1: Definition Perspectives and Key Points

\begin{tabular}{|c|c|c|c|}
\hline $\begin{array}{l}\text { Definition Perspec- } \\
\text { tives }\end{array}$ & Description & $\begin{array}{c}\text { Key Traits of Entre- } \\
\text { preneurs }\end{array}$ & References \\
\hline $\begin{array}{c}\text { Entrepreneur as an } \\
\text { Individual }\end{array}$ & $\begin{array}{l}\text { Entrepreneurship is } \\
\text { referred to the unique } \\
\text { character traits of an } \\
\text { individual having a vi- } \\
\text { sion, able to take risk, } \\
\text { and exploit opportuni- } \\
\text { ties which creates new } \\
\text { firms. }\end{array}$ & $\begin{array}{c}\text { - Risk Taking } \\
\text { - Autonomy } \\
\text { - Create New Firms } \\
\text { - Opportunity Ex- } \\
\text { ploitation } \\
\text { - Innovative Capacity } \\
\text { • Vision } \\
\text { - Bring Change }\end{array}$ & $\begin{array}{l}\text { (Baumgartner, Pütz, \& } \\
\text { Seidl, 2013; Bernier, } \\
\text { 2014; Bernier \& Hafsi, } \\
\text { 2007; González-Pernía, } \\
\text { Jung, \& Peña, 2015; } \\
\text { Llewellyn, Lewis, \& } \\
\text { Woods, 2007; Mack } \\
\text { et al., 2008; Salazar, } \\
\text { 1997) }\end{array}$ \\
\hline Definition Perspectives & Description & Key points & References \\
\hline $\begin{array}{c}\text { Entrepreneurship as a } \\
\text { process }\end{array}$ & $\begin{array}{l}\text { Entrepreneurship is } \\
\text { referred to a process by } \\
\text { which entrepreneurs } \\
\text { pursue opportunities } \\
\text { irrespective of resourc- } \\
\text { es they own in public } \\
\text { enterprises. }\end{array}$ & $\begin{array}{l}\text { - Applying strategic } \\
\text { management practices } \\
\text { - Leadership princi- } \\
\text { ples } \\
\text { - Pursue opportuni- } \\
\text { ties } \\
\text { - Innovativeness } \\
\text { - Risk taking } \\
\text { - Proactiveness } \\
\text { - Idea generation, } \\
\text { translation, \& imple- } \\
\text { mentation }\end{array}$ & $\begin{array}{l}\text { (Bartlett \& Dibben, } \\
\text { 2002; Hafsi, Bernier, } \\
\text { Farashahi, \& Con- } \\
\text { cordia, 2007; Liu \& } \\
\text { Dubinsky, 2000; Nan- } \\
\text { cy C Roberts \& King, } \\
\text { 1991; Zampetakis \& } \\
\text { Moustakis, 2010) }\end{array}$ \\
\hline Definition Perspectives & Description & Key Points & References \\
\hline $\begin{array}{c}\text { Entrepreneurship as } \\
\text { a task }\end{array}$ & $\begin{array}{l}\text { Public entrepreneur- } \\
\text { ship is referred to a } \\
\text { task by which opportu- } \\
\text { nities are created, dis- } \\
\text { covered, and exploited } \\
\text { to create social capital } \\
\text { and value in public } \\
\text { enterprises. }\end{array}$ & $\begin{array}{l}\text { - Discover and exploit } \\
\text { rewarding opportu- } \\
\text { nities. } \\
\text { - Create social capital } \\
\text { and value in public } \\
\text { sector enterprises. } \\
\text { - Create organization. } \\
\text { - Creating opportu- } \\
\text { nities. }\end{array}$ & $\begin{array}{l}\text { (Edwards et al., 2002; } \\
\text { Hayter, 2015; Katsikis } \\
\text { \& Kyrgidou, 2009; } \\
\text { Rennie, 2008; Zerbina- } \\
\text { ti \& Souitaris, 2005) }\end{array}$ \\
\hline
\end{tabular}




\begin{tabular}{|c|c|c|c|}
\hline $\begin{array}{l}\text { Entrepreneurship as a } \\
\text { method }\end{array}$ & $\begin{array}{l}\text { Entrepreneurship } \\
\text { is referred to as a } \\
\text { method or practice of } \\
\text { bringing efficiency and } \\
\text { creativity into public } \\
\text { sector organization } \\
\text { for effective services } \\
\text { delivery. }\end{array}$ & $\begin{array}{l}\text { - Efficiency and } \\
\text { creativity. } \\
\text { - To transform public } \\
\text { organization into flex- } \\
\text { ible units for effective } \\
\text { services delivery. } \\
\text { - Serves to maintain } \\
\text { institutional forms } \\
\text { through social redistri- } \\
\text { bution and change. } \\
\text { - Undertake activities } \\
\text { leading to creation of } \\
\text { organizations. }\end{array}$ & $\begin{array}{l}\text { (Bjerregaard \& Laur- } \\
\text { ing, 2012; Sarasvathy } \\
\text { \& Venkataraman, } \\
\text { 2011; Smith, 2013) }\end{array}$ \\
\hline $\begin{array}{l}\text { Entrepreneurship as } \\
\quad \text { a field }\end{array}$ & $\begin{array}{l}\text { Entrepreneurship is } \\
\text { referred to as a field } \\
\text { which studies the } \\
\text { sources of opportuni- } \\
\text { ties, the processes of } \\
\text { discovery, evaluation } \\
\text { and exploitation of } \\
\text { opportunities and set } \\
\text { of individuals who } \\
\text { discover, evaluate, and } \\
\text { exploit them. }\end{array}$ & $\begin{array}{l}\text { - Sources of opportu- } \\
\text { nities. } \\
\text { - Processes of } \\
\text { discovery, evaluation, } \\
\text { \& exploitation of } \\
\text { opportunities. }\end{array}$ & $\begin{array}{c}\text { (Shane \& Venkatara- } \\
\text { man, 2000) }\end{array}$ \\
\hline
\end{tabular}

\subsection{Goals of entrepreneurship in public sector}

This section presents the analysis of selected article regarding goals of entrepreneurship in public sector. It was revealed that 14 (15.56\%) articles mentioned goals of entrepreneurship in public sector organizations. Baez and Abolafia (2002) mentioned that entrepreneurs are recognized as change agents, innovators, creative and opportunity seeker. Hence, new values could be created into public sector organization for various stakeholders by applying entrepreneurial approach into public sector (Moghaddam et al., 2015). Moreover, the field of entrepreneurship has broaden its horizon into international, policy, social, and not-for profit entrepreneurship which signifies its importance into public sector (Kearney \& Meynhardt, 2016). Following table summarizes the various goals of entrepreneurship that could be achieved by applying entrepreneurial practices, methods, approaches, and mind-set into public sector organizations.

\subsection{Issues and limitations of entrepreneurship in public sector}

This part analyses the various issues and limitations of entrepreneurship discussed 
Table 9: Goals of Entrepreneurship in Public Sector

\begin{tabular}{|c|c|c|}
\hline Description & Objectives & References \\
\hline $\begin{array}{l}\text { Goals which could be achieved } \\
\text { by entrepreneurship in public } \\
\text { sector }\end{array}$ & $\begin{array}{l}\text { - Change institutionalized } \\
\text { practices and routines. } \\
\text { - Introduce innovation for } \\
\text { efficiency and better services } \\
\text { delivery. } \\
\text { - Orientation of risk in public } \\
\text { services. } \\
\text { - Partnership to add value into } \\
\text { public services. } \\
\text { - Leveraging of public Re- } \\
\text { sources. } \\
\text { - Solving problems and satisfy- } \\
\text { ing public needs. } \\
\text { - Discover and exploit oppor- } \\
\text { tunities. } \\
\text { - Foster entrepreneurial mind- } \\
\text { set for entrepreneurial culture. } \\
\text { - Conception and implemen- } \\
\text { adopting an entrepreneurial } \\
\text { approach. } \\
\text { grion of public policies for } \\
\text { - Support for economic devel- } \\
\text { opment at local, regional, and } \\
\text { nalue to citizens. } \\
\text { - level. } \\
\text { - }\end{array}$ & $\begin{array}{l}\text { (Baez \& Abolafia, 2002; Bart- } \\
\text { lett \& Dibben, 2002; Edwards } \\
\text { et al., 2002; Harper-Anderson } \\
\text { \& Gooden, 2016; Lindh \& } \\
\text { Thorgren, 2016; Llewellyn \& } \\
\text { Jones, 2003; Moghaddam et } \\
\text { al., 2015; Zerbinati \& Souitar- } \\
\text { is, 2005) }\end{array}$ \\
\hline
\end{tabular}

in the selected articles regarding its application into public sector organizations. Analyses revealed that 11 (12.22\%) out of 90 selected articles discussed the numerous issues and limitations of entrepreneurship caused by distinct nature, rigid rules and regulations, and culture of public sector organizations. Therefore management models of entrepreneurship into public sector organization presents significant challenges (Emmendoerfer \& Valadares, 2014). Three categories of issues and limitations are identified from selected articles named issues regarding behaviors of entrepreneurs, issues of conflict, and entrepreneurial activity. Following table presents the categories of issues and limitations along with frequency and percentage. 
Table 10: Issues and Limitation of Entrepreneurship in Public Sector

\begin{tabular}{|c|c|}
\hline Categories & $\mathrm{N}$ \\
\hline Issues regarding entrepreneurs behaviors & $7(63.64 \%)$ \\
\hline Issues of conflict & $2(18.18 \%)$ \\
\hline Issues regarding entrepreneurial activity. & $2(18.18 \%)$ \\
\hline Total & $11(100 \%)$ \\
\hline
\end{tabular}

Moreover, following table summarizes the issues and limitation of public entrepreneurship.

Table 10.1: Issues and Limitations of Entrepreneurship in Public Sector

\begin{tabular}{|c|c|c|}
\hline Categories & Issues and Limitations & References \\
\hline Issues of conflicts & $\begin{array}{l}\text { - Entrepreneurial Autonomy } \\
\text { versus Democratic Account- } \\
\text { ability. } \\
\text { - Public Entrepreneurial } \\
\text { Vision versus Citizen Partici- } \\
\text { pation. } \\
\text { - Entrepreneurial Secrecy } \\
\text { versus Democratic Openness. } \\
\text { - Entrepreneurial Risk Taking } \\
\text { versus Democratic Steward- } \\
\text { ship. } \\
\text { - Incompatibility of entrepre- } \\
\text { neurial mind-set with Weberian } \\
\text { tradition rules. }\end{array}$ & $\begin{array}{c}\text { (Bellone \& Goerl, 1992; Berni- } \\
\text { er, 2014) }\end{array}$ \\
\hline $\begin{array}{l}\text { Issues regarding entrepreneurs } \\
\text { behavior }\end{array}$ & $\begin{array}{l}\text { - Character behaviour of } \\
\text { entrepreneurs is not well-suited } \\
\text { for public managers. } \\
\text { - Self-interest of public entre- } \\
\text { preneurs could be a threat to } \\
\text { democratic governance. } \\
\text { - Little agreement regarding } \\
\text { definition of an entrepreneur. } \\
\text { - Risk aversion while dealing } \\
\text { with new and unfamiliar } \\
\text { challenges. } \\
\text { - Lack of interest on the part } \\
\text { of political entrepreneurs. }\end{array}$ & $\begin{array}{l}\text { (Bozeman \& Kingsley, 1998; } \\
\text { Emmendoerfer \& Valadares, } \\
\text { 2014; Harper-Anderson \& } \\
\text { Gooden, 2016; Howard, 2001; } \\
\text { Nancy C Roberts \& King, } \\
\text { 1991; Savaya, Packer, Stange, \& } \\
\text { Namir, 2008; Terry, 1993) }\end{array}$ \\
\hline
\end{tabular}




\begin{tabular}{|c|c|c|}
\hline $\begin{array}{c}\text { Issues regarding entrepreneur- } \\
\text { ial activity. }\end{array}$ & $\begin{array}{c}\text { - Classification of entrepre- } \\
\text { neurial processes and action is } \\
\text { complex. }\end{array}$ & $\begin{array}{c}\text { (Llewellyn \& Jones, 2003; } \\
\text { Zietlow, 2001) }\end{array}$ \\
$\begin{array}{c}\text { Opportunity cost of opportu- } \\
\text { nity exploitation. }\end{array}$ & \\
\hline
\end{tabular}

\subsection{Factors Influencing Entrepreneurship in Public Sector}

This section presents numerous factors which influence entrepreneurship in the public sector. Analyses revealed that 11(12.22\%) studies included in this systematic literature review discussed various factors which influence the entrepreneurial practice in public sector organizations. Zampetakis and Moustakis (2010) presents two main categories of factors which stimulate or hinder entrepreneurship in the public sector, these are institutional factors, and individual factors.

However, in this systematic review four categories of influencing factors are identified from the selected articles. Following table depicts these categories of factors along with frequency and percentages which influence the entrepreneurship in the public sector organizations.

Table 11: Factors Influencing Entrepreneurship in Public Sector

\begin{tabular}{|c|c|}
\hline Categories & $\mathbf{N}$ \\
\hline Individual Factors & $4(36.36 \%)$ \\
\hline Institutional Factors & $3(27.27 \%)$ \\
\hline Social and Political Factors & $3(27.27 \%)$ \\
\hline Legal Factors & $1(9.09 \%)$ \\
\hline Total Articles & $11(100 \%)$ \\
\hline
\end{tabular}

Furthermore, following table depicts the categories along with detailed influencing factors identifies from the analysis of selected articles.

\subsection{Analysis of main research streams in public entrepreneurship}

This section presents the analysis of main research streams identified from selected articles for this systematic review on public entrepreneurship. These research streams are derived from $37(41.11 \%$ ) articles and categorized into seven distinct dimensions which are individual, task, institutional, innovation, business creation, opportunity exploitation, and entrepreneurship as a field of research. Shane and Venkataraman (2000) made an award-winning contribution into the literature by creating conceptual framework for entrepreneurship as a field of research. Similarly, Moghaddam et 
Table 11.1: Categories and Influencing Factors

\begin{tabular}{|c|c|c|}
\hline Categories & Influencing Factors & References \\
\hline Individual Factors & $\begin{array}{l}\text { - Respect for creativity } \\
\text { - Enjoyment of challenge } \\
\text { - Self-confidence } \\
\text { - High tolerance } \\
\text { - Personal autonomy } \\
\text { - Vision for opportunity } \\
\text { - Capacity to innovate } \\
\text { - Technical expertise }\end{array}$ & $\begin{array}{c}\text { (Baumgartner et al., 2013; Lew- } \\
\text { is, 2014; Salazar, 1997; Teske \& } \\
\text { Schneider, 1994) }\end{array}$ \\
\hline Institutional Factors & $\begin{array}{l}\text { - External environment } \\
\text { - Structure of the organization } \\
\text { - Size of the organization } \\
\text { - Culture of the organization } \\
\text { - Degree of specialization } \\
\text { - Centralization of deci- } \\
\text { sion-making } \\
\text { - Clarity of performance } \\
\text { objectives } \\
\text { - System of rewards and } \\
\text { sanctions } \\
\text { - Degree of autonomy } \\
\text { - Institutional venturing, } \\
\text { renewal and frame-breaking } \\
\text { change }\end{array}$ & $\begin{array}{l}\text { (Baumgartner et al., 2013; Liu } \\
\text { \& Dubinsky, 2000; Sadler, } \\
\text { 2000) }\end{array}$ \\
\hline Social and Political Factors & $\begin{array}{c}\text { - Transparency } \\
\text { - Stakeholders participation in } \\
\text { decision-making } \\
\text { - Respect for the others } \\
\text { - Pertinence and fairness of } \\
\text { decisions } \\
\text { - Protection of human rights } \\
\text { - Harmony with national } \\
\text { objectives } \\
\text { - Social justice } \\
\text { - Equal access to service } \\
\text { - Pertinence and coherence of } \\
\text { investment choices }\end{array}$ & $\begin{array}{l}\text { (Baumgartner et al., 2013; } \\
\text { Bernier, 2014; Marie, 2016) }\end{array}$ \\
\hline
\end{tabular}




\begin{tabular}{|l|c|c|}
\hline Legal Factors & $\begin{array}{c}\text { - Policies and Rules regarding } \\
\text { economic development, mon- } \\
\text { etary policy, taxation, health, } \\
\text { education, legislation, industry, } \\
\text { employment, and technology. }\end{array}$ & (Ribeiro-Soriano \& Galin- \\
& do-Martin, 2012) \\
\hline
\end{tabular}

Table 11.1: Categories and Influencing Factors

\begin{tabular}{|c|c|c|}
\hline Dimensions & Research Areas & References \\
\hline $\begin{array}{l}\text { Individual as an } \\
\text { entrepreneur }\end{array}$ & $\begin{array}{l}\text { - Public entrepreneur personality traits. } \\
\text { - Leadership skills of public entrepreneurs. } \\
\text { - Managerial autonomy. } \\
\text { - Eersonal and situational attributes. } \\
\text { - Entrepreneurial behaviour. } \\
\text { - Entrepreneurial vision for entrepreneurial } \\
\text { action. } \\
\text { - Needs of entrepreneurs in public sector. }\end{array}$ & $\begin{array}{l}\text { (Fernando, 2005; Gupta, Mac- } \\
\text { Millan, \& Surie, 2004; Kayasan, } \\
\text { 2011; Lewis, 2014; Llewellyn } \\
\text { et al., 2007; Mack et al., 2008; } \\
\text { Salazar, 1997; Zampetakis \& } \\
\text { Moustakis, 2010) }\end{array}$ \\
\hline Task Dimension & $\begin{array}{l}\text { - What do public entrepreneurs do? } \\
\text { - Entrepreneurial activities. } \\
\text { - Product and process based entrepreneur- } \\
\text { ship. }\end{array}$ & $\begin{array}{l}\text { (Bernier \& Hafsi, 2007; Hafsi et } \\
\text { al., 2007; Moon, 1999; Schum- } \\
\text { peter, 1934) }\end{array}$ \\
\hline $\begin{array}{l}\text { Institutional } \\
\text { Dimension }\end{array}$ & $\begin{array}{l}\text { - Institutional entrepreneurship } \\
\text { - Institutional change process through sense } \\
\text { making. } \\
\text { - Collective and collaborative entrepreneur- } \\
\text { ship. } \\
\text { - Corporate entrepreneurship. } \\
\text { - Motivation for entrepreneurship services. } \\
\text { - Components of corporate entrepreneurship } \\
\text { strategy in public sector. } \\
\text { - Suitability of market-driven entrepreneur- } \\
\text { ial practices into public sector; similarities, } \\
\text { constraints, and prospects. } \\
\text { - Strategic entrepreneurship. }\end{array}$ & $\begin{array}{l}\text { (Baez \& Abolafia, 2002; Harp- } \\
\text { er-Anderson \& Gooden, 2016; } \\
\text { Hartley, Sørensen, \& Torfing, } \\
\text { 2013; Kearney \& Meynhardt, } \\
\text { 2016; Liu \& Dubinsky, 2000; } \\
\text { Luke \& Verreynne, 2006; Nancy } \\
\text { C. Roberts, 2006; Zampetakis \& } \\
\text { Moustakis, 2007b) }\end{array}$ \\
\hline $\begin{array}{l}\text { Innovation } \mathrm{Di} \text { - } \\
\text { mension }\end{array}$ & - Innovation in service delivery & (Llewellyn \& Jones, 2003) \\
\hline
\end{tabular}




\begin{tabular}{|c|c|c|}
\hline $\begin{array}{c}\text { Creating New } \\
\text { Business }\end{array}$ & - New ventures and SMEs. & $\begin{array}{l}\text { (Cheng, Stough, \& Jackson, } \\
\text { 2009) }\end{array}$ \\
\hline $\begin{array}{l}\text { Opportunity } \\
\text { Exploitation }\end{array}$ & $\begin{array}{l}\text { - Generating and scanning new ideas for } \\
\text { viable proposals. }\end{array}$ & $\begin{array}{c}\text { (Nancy C Roberts \& King, } \\
\text { 1991) }\end{array}$ \\
\hline $\begin{array}{l}\text { Entrepreneurship } \\
\text { as field }\end{array}$ & $\begin{array}{l}\text { - Nature, constraints, and boundaries of } \\
\text { entrepreneurship in public sector. } \\
\text { - Social value creation. } \\
\text { - Characteristics of entrepreneurship. } \\
\text { - Applying Market mechanism into public } \\
\text { management problems. } \\
\text { - Paradigm of public entrepreneurships. } \\
\text { - Culture influence on entrepreneurship. } \\
\text { - Academic entrepreneurship. } \\
\text { - Knowledge spill over theory of entrepre- } \\
\text { neurship. } \\
\text { - Entrepreneurship for economic develop- } \\
\text { ment. } \\
\text { - Entrepreneurial stakeholders in public } \\
\text { sector. } \\
\text { - Entrepreneurship theory. } \\
\text { - Creating social and societal values through } \\
\text { entrepreneurship. } \\
\text { - Contextual antecedents of entrepreneur- } \\
\text { ship. }\end{array}$ & $\begin{array}{l}\text { (Audretsch, 2004; Dahles, } \\
\text { Verduyn, Wakkee, Lund- } \\
\text { qvist, \& Williams Middleton, } \\
\text { 2010; Doherty et al., 2006; } \\
\text { González-Pernía et al., 2015; } \\
\text { Hayter, 2015; Hjorth, 2013; Kat- } \\
\text { sikis \& Kyrgidou, 2009; Klein, } \\
\text { Mahoney, McGahan, \& Pitelis, } \\
\text { 2010; Lindh \& Thorgren, 2016; } \\
\text { Nayyar \& Sohail H. Naqvi, } \\
\text { 2013; Schumpeter, 1934; Seo \& } \\
\text { Chung, 2012; Steyaert \& Katz, } \\
\text { 2004; Su, Zhai, \& Landström, } \\
\text { 2015; Xu \& Carey, 2015) }\end{array}$ \\
\hline
\end{tabular}

al. (2015) made an attempt to articulate the conceptual model of entrepreneurship and studied its importance for bolstering performance of government organizations.

Moreover, Baumgartner et al. (2013) reviewed an extensive literature to identify various comprehensions of entrepreneurship and their role for regional development. Whereas, still there is no agreement of scholars about the unique identity of entrepreneurship as after the analysis of research articles it looks a hodgepodge having no clear direction as a field of research.

Following table depicts the main conceptual and theoretical areas of research about entrepreneurship identified from selected research articles.

\section{Conclusion}

As $21^{\text {st }}$ century has witnessed an unprecedented change in the environment of public organization which has created unpredicted challenges for the public administrators. Hence, conventional approaches are not sufficient to cater the complex 
and elusive challenges of this century (Moghaddam et al., 2015). Therefore, public administrators and political leaders has focused to foster entrepreneurship into public sector organizations in order to improve their performance (Luke \& Verreynne, 2006).

Notion of entrepreneurship has been seen as inherently private (Salazar, 1997) but with a widespread application of entrepreneurial practices into public sector organizations. This perspective has been changed after NPM movement which was focused on improving the performance of public sector organizations for efficient and effective delivery of public services (Klein et al., 2010). Moreover, various studies have unleashed the social potential of entrepreneurship along with its market based orientation (Zampetakis \& Moustakis, 2007a). Scholars have acknowledged that entrepreneurship methods must be modified and adjusted according to the demands of public sector. (Zampetakis \& Moustakis, 2007b).

Application of entrepreneurial mind-set into public sector for improved performance of state enterprises has been the key issue of discourse of entrepreneurship literature. Moreover, what is public entrepreneurship? Is it different from private notion of entrepreneurship? Are entrepreneurial methods compatible with democratic structure? Who are public entrepreneurs? And what are their characteristics? How do they improve service delivery of public organizations? These are few basic questions about the concept, nature, applicability and implementation of entrepreneurship into public sector organizations.

This study was conducted to investigate the phenomenon of entrepreneurship with particular reference to public sector by adopting the methodology of systematic literature review. Methodology of this systematic literature review of public entrepreneurship is adopted with the review of (De Vries et al., 2016) which was conducted on innovation in public sector. This study endeavored to explore the concept of public entrepreneurship, its current practices, goals, limitations and possibilities, major research streams, their emergence, convergence, and divergence points, antecedents in public sector. Out of total 572 research articles searched from six databases by applying inclusion and exclusion criteria mentioned in detail in methodology section, 90 articles were found eligible for this systematic review on public entrepreneurship.

Analysis revealed that majority of the articles included in this review were published during 2011 to 2016 in North American and European countries. USA, UK and Australia were the top three countries in which mostly studies were conducted. Public Administration Review, Entrepreneurial and Regional Development, and Public Management Review are the top three journals in which majority articles were published. Majority studies were empirical which followed qualitative strategy in their research designs. Further case study design was significantly used in the qualitative 
studies, followed by exploratory and secondary data analysis. Majority of the quantitative design articles used survey approach.

Moreover, analysis of main research questions about entrepreneurship definitions, its goals in public sector, its issues and limitations, influencing factors and main research streams revealed very interesting and comprehensive results. Analysis of definitions revealed five main dimensions of entrepreneurship in which it was defined. Majority referred it as an individual having certain unique characteristics which distinguish entrepreneurs from other individuals. Main emphasis of studies was on entrepreneurs' key traits like having a vision, exploit opportunities, take risk, and bring innovation into existing processes and practices. Further focused dimensions were task and process in which entrepreneurship was referred as a task and process to exploit opportunities and create new ventures, and innovation into the firms.

Next question about goals of entrepreneurship revealed numerous objectives which could be achieved by applying entrepreneurial practices into public sector firms. Changing institutional routines, introducing innovation for efficient service delivery, and add social value into public services were the main goals which are to be achieved by the entrepreneurship into public sector.

While analyzing issues and limitations of entrepreneurship into public sector it was revealed that management models of entrepreneurship into public organizations presents significant challenges due to the innate capacity of entrepreneurship embedded in private sector organizations. Majority studies discussed issues related to entrepreneurs' behavior which are not compatible to public sector organization due to their democratic and bureaucratic structures. Certain issues of theoretical nature like issues of conflicts i-e entrepreneurial autonomy and democratic accountability, entrepreneurial secrecy versus democratic openness were also found in the discourse of entrepreneurship scholarship.

Four categories of influencing factors were derived from the analysis of selected articles in which majority were individual, institutional, and social and political factors. In individual visions for opportunity exploitation, capacity to innovate, self-confidence, tolerance, and technical expertise were main influencing factors. Institutional venturing, structure, rules, environment, systems of rewards, delegations, and decision making were the main institutional factors. Transparency, social justice, harmony with national objectives, access to services were the main social and political factors.

Similarly, while analyzing major theoretical research areas from the studies it was revealed that focus of majority was entrepreneurship as a field of research rather confining it to some specific individual, process or activity. Entrepreneurship nature, 
paradigm, method, as a theory, contextual antecedents and implications were the main research streams. Second discussed research area was its institutional dimension in which institutional entrepreneurship, collaborative and collective entrepreneurship, corporate entrepreneurship, and strategic entrepreneurship were mainly focused. Third major research stream focus was on individual and behavioral characteristics of entrepreneurs. Public entrepreneurs' personality traits, entrepreneurial leaders, entrepreneurial vision, and gender narratives were mainly focused. However, much acknowledged dimensions like venture creation, innovation was less focused in the literature of public entrepreneurship whereas they are leading dimensions of entrepreneurship when it comes to private sector.

Summing it up, this study conducted systematic review of literature on public entrepreneurship. Various facets of entrepreneurship were analyzed with reference to public sector orientation. Entrepreneurship in the public sector has gained enormous currency due to its embedded capacity for innovation, creativity, opportunity exploitation, and solving elusive problems of the $21^{\text {st }}$ century. Public entrepreneurs are widely acknowledged across the globe for their significant contribution in improvement of public services and creating social value for the citizens (Luke \& Verreynne, 2006). As far as the field of entrepreneurship is concerned, no unanimous definition exists in the literature; it could be due to its widespread scope and applicability.

Note: All 90 articles references are not mentioned in the bibliography.

\section{References}

Audretsch, D. B. (2004). Sustaining innovation and growth: Public policy support for entrepreneurship. Industry $\mathcal{E}$ Innovation, 11(3), 167-191. doi: 10.1080/1366271042000265366

Baez, B., \& Abolafia, M. Y. (2002). Bureaucratic entrepreneurship and institutional change: a sense-making approach. Journal of Public Administration Research and Theory, 12(4), 525-552.

Bartlett, D., \& Dibben, P. (2002). Public sector innovation and entrepreneurship: Case studies from local government. Local Government Studies, 28(4), 107-121. doi: 10.1080/714004159

Baumgartner, D., Pütz, M., \& Seidl, I. (2013). What kind of entrepreneurship drives regional development in european non-core regions? A literature review on empirical entrepreneurship research. European Planning Studies, 21(8), 1095-1127. doi: 10.1080/09654313.2012.722937

Bellone, C. J., \& Goerl, G. F. (1992). Reconciling public entrepreneurship and democracy. Public Administration Review, 52(2) 130-134.

Bernier, L. (2014). Public enterprises as policy instruments: the importance of public entrepreneurship. Journal of Economic Policy Reform, 17(3), 253-266. doi: 10.1080/17487870.2014.909312 
Bernier, L., \& Hafsi, T. (2007). The changing nature of public entrepreneurship. Public Administration Review, 67(3), 488-503.

Bjerregaard, T., \& Lauring, J. (2012). Entrepreneurship as institutional change: Strategies of bridging institutional contradictions. European Management Review, 9(1), 31-43.

Bozeman, B., \& Kingsley, G. (1998). Risk culture in public and private organizations. Public Administration Review, 58(2),109-118.

Cheng, S., Stough, R. R., \& Jackson, R. W. (2009). Measuring and building high-quality entrepreneurship: A research prospectus. Innovation: The European Journal of Social Science Research, 22(3), 329-340. doi: $10.1080 / 13511610903399088$

Dahles, H., Verduyn, K., Wakkee, I., Lundqvist, M. A., \& Williams Middleton, K. L. (2010). Promises of societal entrepreneurship: Sweden and beyond. Journal of Enterprising Communities: People and Places in the Global Economy, 4(1), 24-36.

De Vries, H., Bekkers, V., \& Tummers, L. (2016). Innovation in the Public Sector: A Systematic Review and Future Research Agenda. Public Administration, 94(1), 146-166. doi: 10.1111/padm.12209

Doherty, B., Thompson, J., \& Spear, R. (2006). Social entrepreneurship: A different model? International Journal of Social Economics, 33(5/6), 399-410.

Edwards, C., Jones, G., Lawton, A., \& Llewellyn, N. (2002). Public entrepreneurship: Rhetoric, reality, and context. International Journal of Public Administration, 25(12), 1539-1554. doi: 10.1081/pad-120014260

Emmendoerfer, M., \& Valadares, J. L. (2014). Analysis of the public entrepreneurship phenomenon in a Brazilian state. Tourism E⿱ Management Studies, 10, 43-48.

Fernando, R. L. S. (2005). Entrepreneurship in delivery of service in public sector organization in Sri Lanka: Prospects for administrative and managerial reforms. Paper presented at the Network of Asia-Pacific Schools and Institutes of Public Administration and Governance (NAPSIPAG) Annual Conference 2005, Beijing, China.

González-Pernía, J. L., Jung, A., \& Peña, I. (2015). Innovation-driven entrepreneurship in developing economies. Entrepreneurship $\mathcal{E}$ Regional Development, 27(9-10), 555-573. doi: $10.1080 / 08985626.2015 .1075602$

Gupta, V., MacMillan, I. C., \& Surie, G. (2004). Entrepreneurial leadership: Developing and measuring a cross-cultural construct. Journal of Business Venturing, 19(2), 241-260.

Hafsi, T., Bernier, L., Farashahi, M., \& Concordia, J. (2007). Institutional entrepreneurs in the public sector: Towards a contingency theory. Cahier de recherche N, 7, 30-01.

Harper-Anderson, E. L., \& Gooden, S. T. (2016). Integrating entrepreneurship services into local workforce development systems: Who is doing it and how. Journal of Poverty, 20(3), 237-260. doi: 10.1080/10875549.2015.1094769 
Hartley, J., Sørensen, E., \& Torfing, J. (2013). Collaborative innovation: A viable alternative to market competition and organizational entrepreneurship. Public Administration Review, 73(6), 821-830. doi: $10.1111 /$ puar.12136

Hayter, C. S. (2015). Public or private entrepreneurship? Revisiting motivations and definitions of success among academic entrepreneurs. The Journal of Technology Transfer, 40(6), 1003-1015.

Hjorth, D. (2013). Public entrepreneurship: Desiring social change, creating sociality. Entrepreneurship E Regional Development, 25(1-2), 34-51. doi: 10.1080/08985626.2012.746883

Howard, C. (2001). Bureaucrats in the social policy process: Administrative policy entrepreneurs and the case of working nation. Australian Journal of Public Administration, 60(3), 56-65.

Katsikis, I. N., \& Kyrgidou, L. P. (2009). Entrepreneurship in teleology: The variety of the forms. International Journal of Entrepreneurial Behavior E Research, 15(2), 209-231.

Kayasan, O. (2011). The role of regimes to generate a new form of entrepreneurship: Central asian perspectives. Procedia-Social and Behavioral Sciences, 24, 526-537.

Kearney, C., \& Meynhardt, T. (2016). Directing corporate entrepreneurship strategy in the public sector to public value: Antecedents, components, and outcomes. International Public Management Journal, 1-30. doi: $10.1080 / 10967494.2016 .1160013$

Klein, P. G., Mahoney, J. T., McGahan, A. M., \& Pitelis, C. N. (2010). Toward a theory of public entrepreneurship. European Management Review, 7(1), 1-15.

Lewis, K. V. (2014). Public narratives of female entrepreneurship: fairy tale or fact? Labour $\mathcal{E}$ Industry: A journal of the social and economic relations of work, 24(4), 331-344. doi: 10.1080/10301763.2014.978967

Lindh, I., \& Thorgren, S. (2016). Entrepreneurship education: The role of local business. Entrepreneurship EF Regional Development, 1-24. doi: 10.1080/08985626.2015.1134678

Liu, S. S., \& Dubinsky, A. J. (2000). Institutional entrepreneurship-A panacea for universities-in-transition? European Journal of Marketing, 34(11/12), 1315-1337.

Llewellyn, N., \& Jones, G. (2003). Controversies and conceptual development examining public entrepreneurship. Public Management Review, 5(2), 245-266. doi: 10.1080/1461667032000066426

Llewellyn, N., Lewis, P., \& Woods, A. (2007). Public management and the expansion of an entrepreneurial ethos? Public Management Review, 9(2), 253-267. doi: 10.1080/14719030701340424

Luke, B., \& Verreynne, M.-L. (2006). Exploring strategic entrepreneurship in the public sector. Qualitative Research in Accounting $\mathcal{E}$ Management, 3(1), 4-26.

Mack, W., Green, D., \& Vedlitz, A. (2008). Innovation and implementation in the public sector: An examination of public entrepreneurship. Review of policy research, 25(3), 233-252.

Marie, T. T. (2016). Public values as essential criteria for public entrepreneurship: Water management 
in France. Utilities Policy, 40, 162-169.

Robinson, M. (2015). From old public administration to the new public service: Implications for public sector reform in developing countries. UNDP Global Centre for Public Service Excellence.

Moghaddam, J. Y., Khorakian, A., \& Maharati, Y. (2015). Organizational entrepreneurship and its impact on the performance of governmental organizations in the city of Mashhad. Procedia-Social and Behavioral Sciences, 169, 75-87.

Moon, M. J. (1999). The pursuit of managerial entrepreneurship: Does organization matter? Public Administration Review, 31-43.

Nayyar, J., \& Sohail H. Naqvi, S. (2013). Proposed model of entrepreneurial mindset for the state government higher education institutions in Pakistan. Journal of Enterprising Communities: People and Places in the Global Economy, 7(2), 167-182.

Perlmutter, F. D., \& Cnaan, R. A. (1995). Entrepreneurship in the public sector: The horns of a dilemma. Public Administration Review, 29-36.

Rennie, H. G. (2008). Entrepreneurship as a liberal art. Politics $\mathcal{E}$ Policy, 36(2), 197-215.

Ribeiro-Soriano, D., \& Galindo-Martín, M.Á. (2012). Government policies to support entrepreneurship. Entrepreneurship E Regional Development, 24(9-10), 861-864. doi: 10.1080/08985626.2012.742322

Roberts, N. C. (2006). Public entrepreneurship as social creativity. World Futures, 62(8), 595-609. doi: $10.1080 / 02604020600948909$

Roberts, N. C., \& King, P. J. (1991). Policy entrepreneurs: Their activity structure and function in the policy process. Journal of Public Administration Research and Theory, 1(2), 147-175.

Sadler, R. J. (2000). Corporate entrepreneurship in the public sector: The dance of the chameleon. Australian Journal of Public Administration, 59(2), 25-43.

Salazar, G. (1997). Public entrepreneurship: A contradiction in terms? Korean Review of Public Administration, 2(1), 125-139.

Sarasvathy, S. D., \& Venkataraman, S. (2011). Entrepreneurship as method: Open questions for an entrepreneurial future. Entrepreneurship Theory and Practice, 35(1), 113-135. doi: 10.1111/j.1540$6520.2010 .00425 . x$

Savaya, R., Packer, P., Stange, D., \& Namir, O. (2008). Social entrepreneurship: Capacity building among workers in public human service agencies. Administration in Social Work, 32(4), 65-86. doi: $10.1080 / 03643100802293840$

Schumpeter, J. A. (1934). The theory of economic development: An inquiry into profits, capital, credit, interest, and the business cycle. Transaction publishers.

Seo, J., \& Chung, S. (2012). Impact of entrepreneurship in the public sector: Cheonggye stream res- 
toration project in the Seoul metropolitan city. Asia Pacific Journal of Public Administration, 34(1), 71-93. doi: 10.1080/23276665.2012.10779388

Shane, S., \& Venkataraman, S. (2000). The promise of entrepreneurship as a field of research. Academy of Management Review, 25(1), 217-226.

Smith, E. (2013). Entrepreneurship at the local government level: Stimulating and restraining forces in the swedish waste management industry. Public Management Review, 16(5), 708-732. doi: $10.1080 / 14719037.2012 .743580$

Steyaert, C., \& Katz, J. (2004). Reclaiming the space of entrepreneurship in society: geographical, discursive and social dimensions. Entrepreneurship EF Regional Development, 16(3), 179-196. doi: $10.1080 / 0898562042000197135$

Su, J., Zhai, Q., \& Landström, H. (2015). Entrepreneurship research in China: internationalization or contextualization? Entrepreneurship $\mathcal{E}$ Regional Development, 27(1-2), 50-79. doi: $10.1080 / 08985626.2014 .999718$

Terry, L. D. (1993). Why we should abandon the misconceived quest to reconcile public entrepreneurship with democracy: A response to Bellone and Goerl's" Reconciling Public Entrepreneurship And Democracy". Public Administration Review, 53(4), 393-395.

Teske, P., \& Schneider, M. (1994). The bureaucratic entrepreneur: The case of city managers. Public Administration Review, 54(4), 331-340.

Vecchi, V., Brusoni, M., \& Borgonovi, E. (2014). Public authorities for entrepreneurship: A management approach to execute competitiveness policies. Public Management Review, 16(2), 256-273.

Wagner, M., \& Schaltegger, S. (2010). Classifying entrepreneurship for the public good: Empirical analysis of a conceptual framework. Journal of Small Business $\mathcal{E}$ Entrepreneurship, 23(3), 431-443. doi: $10.1080 / 08276331.2010 .10593494$

Xu, J., \& Carey, R. (2015). Post-2015 global governance of official development finance: Harnessing the renaissance of public entrepreneurship. Journal of International Development, 27(6), 856-880. doi: $10.1002 /$ jid. 3120

Zampetakis, L. A., \& Moustakis, V. (2007a). Entrepreneurial behaviour in the Greek public sector. International Journal of Entrepreneurial Behavior EF Research, 13(1), 19-38.

Zampetakis, L. A., \& Moustakis, V. (2007b). Fostering corporate entrepreneurship through internal marketing: Implications for change in the public sector. European Journal of Innovation Management, 10(4), 413-433.

Zampetakis, L. A., \& Moustakis, V. S. (2010). An exploratory research on the factors stimulating corporate entrepreneurship in the Greek public sector. International Journal of Manpower, 31(8), 871-887.

Zerbinati, S., \& Souitaris, V. (2005). Entrepreneurship in the public sector: A framework of analy- 
sis in European local governments. Entrepreneurship $\mathcal{E}$ Regional Development, 17(1), 43-64. doi: $10.1080 / 0898562042000310723$

Zietlow, J. T. (2001). Social entrepreneurship: managerial, finance and marketing aspects. Journal of Nonprofit E Public Sector Marketing, 9(1-2), 19-43. doi: 10.1300/J054v09n01_03 
